\title{
Hepatozoon spp. infections in wild rodents in an area of endemic canine hepatozoonosis in southeastern Brazil
}

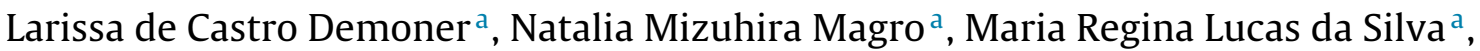 \\ João Marcelo Azevedo de Paula Antunes ${ }^{\mathrm{b}}$, Cecilia Irene Pérez Calabuig ${ }^{\mathrm{b}}$, \\ Lucia Helena O'Dwyer ${ }^{\mathrm{a}, *}$ \\ a Instituto de Biociências, UNESP-Univ Estadual Paulista, Campus de Botucatu, Departamento de Parasitologia, Distrito de Rubião Junior, Botucatu, São \\ Paulo, Brazil \\ ${ }^{\mathrm{b}}$ Departamento de Ciências Animais, Universidade Federal Rural do Semiárido, Av. Francisco Mota 572, Mossoró, Rio Grande do Norte, Brazil
}

\section{A R T I C L E I N F O}

\section{Article history:}

Received 28 February 2016

Received in revised form 6 April 2016

Accepted 7 April 2016

Available online 12 April 2016

\section{Keywords:}

Hepatozoon canis

Transmission

Paratenic hosts

Dogs

Wild rodents

\begin{abstract}
A B S T R A C T
Hepatozoon canis is a tick-borne parasite that occurs worldwide. In rural areas of Brazil, $H$. canis vectors remain unknown, which has led to speculation about alternative routes of transmission. Small rodents can play a role in the transmission (via predation) of Hepatozoon americanum, which led us to question whether predation might be an alternative mode of transmission for $H$. canis. Thus, this study investigated whether Hepatozoon spp. are present in wild small rodents in forest fragments that surround rural areas in Botucatu County, São Paulo, Brazil, where canine hepatozoonosis is endemic. The study included blood samples from 158 dogs, which were screened by microscopy and molecular analysis. Blood samples and tissues from 67 rodents were obtained for histopathology and molecular detection. The prevalence of $H$. canis was high (66.45\%) in dogs from rural areas of Botucatu, São Paulo, Brazil. The molecular analysis showed that wild rodent species in Brazil were infected with Hepatozoon spp. other than $H$. canis. Therefore, although the hypothesis that sylvatic rodents act as reservoirs for $H$. canis was not supported, the presence of monozoic cysts in the rodents suggests that, in addition to intermediate hosts, wild small rodents in Brazil might act as paratenic hosts of Hepatozoon spp. because they harbor infective stages for intermediate host predators.
\end{abstract}

(c) 2016 Elsevier GmbH. All rights reserved.

\section{Introduction}

Hepatozoon species (phylum Apicomplexa) are blood parasites that use a wide range of vertebrates as intermediate hosts, including amphibians, reptiles, birds, and domestic and wild mammals (Smith, 1996; Baneth et al., 2003). Members of this genus exhibit a complex and obligate heteroxenous life cycle in which oocysts form in invertebrate definitive hosts (Smith et al., 1999; Baneth et al., 2007) and transmission to vertebrate intermediate hosts commonly occurs through the ingestion of infected invertebrate hosts (various blood-sucking arthropods) (Smith, 1996).

Hepatozoonosis caused by Hepatozoon canis is a canine tickborne disease that occurs worldwide (Baneth, 2011; Aktas et al., 2015). The brown dog tick, Rhipicephalus sanguineus sensu lato (s.l.), is the main vector of the disease (Baneth et al., 2007; Giannelli

\footnotetext{
* Corresponding author.

E-mail address: odwyer@ibb.unesp.br (L.H. O’Dwyer).
}

et al., 2013); however, studies indicate the existence of a " $R$. sanguineus group", although the number of species in the group is uncertain (Dantas-Torres and Otranto, 2015; Nava et al., 2015), which suggests that the vector competence of this tick species for $H$. canis might differ among geographical regions (Dantas-Torres and Otranto, 2015). In Hungary, for example, Hornok et al. (2013) found a high prevalence of canine hepatozoonosis in regions where $R$. sanguineus s.l. is not considered to be endemic. In Brazil, apparently, the tropical lineage of $R$. sanguineus s.l. is not associated with the transmission of the protozoan (Rubini et al., 2009; Demoner et al., 2013).

In addition to infection through the ingestion of ticks, nonvector transmission of $H$. canis has been demonstrated (e.g., vertical transmission) (Murata et al., 1993). Several studies have strongly suggested that Hepatozoon americanum (the causative agent of canine hepatozoonosis in the USA) can be transmitted by predation (ingestion of cystic forms of the parasite in laboratory rodents and rabbits) (Johnson et al., 2008a; Johnson et al., 2008b; Johnson et al., 2009a). Furthermore, in the southeastern USA, case reports have 
linked $H$. americanum infection to a high proportion of dogs that had access to natural prey (Johnson et al., 2009b). Epidemiological data have indicated a high prevalence of $H$. canis infections among dogs in rural areas of Brazil (O'Dwyer, 2011). In rural areas, dogs often roam the forests and, probably, engage in predation (Rubini et al., 2008; de Miranda et al., 2014).

In Brazil, $H$. canis DNA has been detected in Amblyomma cajennese sensu lato; however, this group of ticks might not play a role as vectors (Melo et al., 2016). Additionally, although H. canis oocysts have been identified in Rhipicephalus microplus (formerly, Boophilus microplus) and Amblyomma ovale ticks (Forlano et al., 2005; de Miranda et al., 2011), the vector competence of these ticks is unknown.

Hepatozoon species have been identified in wild small rodents in Europe (Laakkonen et al., 2001; Criado-Fornelio et al., 2006), Africa (Maia et al., 2014), North America (Johnson et al., 2007) and South America (Wolf et al., 2016). Although they are important reservoirs for various vector-borne pathogens and have an important trophic position, which have implications for predator-prey transmission, information about Hepatozoon spp. infecting wild rodent populations is lacking. The vector competence of tick species in the transmission of $H$. canis in Brazil is not well understood; therefore, there might be unknown epidemiological aspect(s) (e.g., ingestion of cystozoite forms in paratenic hosts). Within that context, this study investigated whether Hepatozoon spp. are present in wild rodents in forest fragments near rural areas in Botucatu County, São Paulo, southeastern Brazil, where canine hepatozoonosis is endemic.

\section{Material and methods}

\subsection{Dog sampling}

Between January and June 2013, 158 apparently asymptomatic dogs were randomly sampled from 40 rural households in the municipality of Botucatu, São Paulo, southeastern Brazil. EDTA blood samples were obtained from cephalic or jugular veins for use in the isolation of DNA. Thin blood smears were taken from the marginal veins of the ear, fixed with metanol, stained with Giemsa, and screened for Hepatozoon gametocytes.

Each dog was inspected for ectoparasites. Fleas and ticks were removed and stored in 70\% ethanol. Ectoparasites were identified using a stereomicroscope and taxonomic keys (Barros-Battesti et al., 2006; Martins et al., 2010; Linardi and Santos, 2012). To investigate the presence of Hepatozoon oocysts in the hemocoel, ticks were dissected following the procedure of Demoner et al. (2013).

\subsection{Trapping of wild rodents and sample collection}

Between September 2013 and June 2014, 67 rodents belonging to five species were live-trapped in forest fragments that surrounded the rural communities in which the domestic dogs were examined. Rodents were collected along terrestrial linear transects using pitfalls traps (each pitfall line consisted of six 60-1 buckets spaced $10 \mathrm{~m}$ apart) and aluminum Sherman traps $(31 \times 8 \times 9 \mathrm{~cm}$; each transect consisted of 20 Sherman traps spaced at $2 \mathrm{~m}$ intervals). Trapping occurred on seven consecutive days, and traps were baited with a mixture of peanut butter, canned sardines, cornmeal, and oatmeal, which has been considered an effective attractant for wild rodents (Peres et al., 2013).

For tissue collection and necropsy, each captured rodent was anesthetized by isoflurane inhalation and weighed, and for DNA isolation, peripheral blood samples were obtained by cardiac puncture. Rodents were euthanized by increasing the anesthetic dose and their organs were removed. Tissue samples were collected for
PCR assays and histopathological analysis. For histological analyses, tissues were formalin-fixed, paraffin-embedded, sliced at a $5 \mu \mathrm{m}$ thickness, and stained with hematoxylin and eosin (H\&E). To prevent, for example, Hantavirus and Arenavirus infections, the rodents were trapped and handled following biosafety guidelines (Mills et al., 1995).

\subsection{DNA isolation, amplification and sequencing}

Genomic DNA was extracted from the dog blood samples (approximately $200 \mu \mathrm{l}$ ) and from the rodent samples $(100-200 \mu \mathrm{l}$ of blood and $20-50 \mathrm{mg}$ of skeletal muscle, spleen, and liver) using the Illustra Blood genomicPrep Mini Spin Kit ${ }^{\circledR}$ and the Illustra Tissue Mini Spin Kit ${ }^{\circledR}$ (GE Healthcare, Buckinghamshire, UK), following the protocols provided by the manufacturer. PCR reactions were performed in a total volume of $25 \mu$ l containing $12.5 \mu$ l of GoTaq ${ }^{\circledR}$ Colorless Master Mix (Promega Corporation, WI, USA), $1 \mu$ l of each primer, $5 \mu \mathrm{l}$ of DNA and $5.5 \mu \mathrm{l}$ of ultra-pure sterile water. A negative (distilled sterile water) and a positive ( $H$. canis-positive dog) control were used in each reaction.

For the PCR screening of the canine blood samples, the primer pair HepF (5'-ATA-CAT-GAG-CAA-AAT-CTC-AAC-3') and HepR (5' CTT-ATT-ATT-CCA-TGC-TGC-AG-3') was used to amplify a 666-bp fragment of the $18 \mathrm{~S}$ ribosomal RNA gene of Hepatozoon spp. (Inokuma et al., 2002). The PCR parameters were $94^{\circ} \mathrm{C}$ for $3 \mathrm{~min}$, followed by 37 cycles at $94^{\circ} \mathrm{C}$ for $45 \mathrm{~s}$, annealing at $57^{\circ} \mathrm{C}$ for $45 \mathrm{~s}$, extension at $72^{\circ} \mathrm{C}$ for $1 \mathrm{~min}$, and at $72^{\circ} \mathrm{C}$ for $7 \mathrm{~min}$.

Detection of Hepatozoon species in rodent blood and tissues was performed by conventional PCR using the primers HepF300 (5'-GTT-TCT-GAC-CTA-TCA-GCT-TTC-GAC-G-3') and Hep900 (5'CAA-ATC-TAA-GAA-TTT-CAC-CTC-TGA-C-3'), which target a 600bp fragment of the 18S rRNA gene of Hepatozoon spp. (Ujvari et al., 2004). The reactions were performed using the following parameters: $94^{\circ} \mathrm{C}$ for $3 \mathrm{~min}, 35$ cycles at $94^{\circ} \mathrm{C}$ for $45 \mathrm{~s}, 56^{\circ} \mathrm{C}$ for $1 \mathrm{~min}, 72^{\circ} \mathrm{C}$ for $1 \mathrm{~min}$, and a final extension step of $72{ }^{\circ} \mathrm{C}$ for $7 \mathrm{~min}$.

For additional phylogenetic analysis, a second PCR protocol targeted a larger segment (approximately $1120 \mathrm{bp}$ ) of the $18 \mathrm{~S}$ rRNA gene in some of the dog samples and all of the rodent samples that tested positive for Hepatozoon species in the first PCR. The primer pair 4558 (5-'GCT-AAT-ACA-TGA-GCA-AAA-TCT-CAA-3') and 2733 (5'-CGG-AAT-TAA-CCA-GAC-AAA-T-3') was used (Mathew et al., 2000). The following amplification conditions were used for that reaction: $94^{\circ} \mathrm{C}$ for $3 \mathrm{~min}$, followed by 40 cycles of $94^{\circ} \mathrm{C}$ for $1 \mathrm{~min}$, annealing at $56^{\circ} \mathrm{C}$ for $1 \mathrm{~min}, 72^{\circ} \mathrm{C}$ for $90 \mathrm{~s}$ and, following the cycles, a final extension of $72^{\circ} \mathrm{C}$ for $7 \mathrm{~min}$.

The resulting amplicons were viewed under ultraviolet light on $1 \%$ agarose gel ( $80 \mathrm{~V}, 60 \mathrm{~min})$ stained with GelRed ${ }^{\mathrm{TM}}$ (Biotium, Hayward, USA), and were measured by comparison with $1 \mathrm{~Kb}$ plus DNA Ladder (Invitrogen, Carlsbad, EUA) as a molecular marker. The PCR products were purified using Illustra ExoProStar 1-Step (GE Healthcare, Buckinghamshire, UK), then sequenced directly using the Taq DyeDeoxyTerminator Cycle Sequencing Kit (v.2, Applied Biosystems, USA) in an automated sequencer (ABI-PRISM 377, Applied Biosystems). Sequences were edited using BioEdit software, version 7.2.5 (Hall, 1999) and compared for similarity to the sequences available in GenBank (http://www.ncbi.nlm.nih.gov/BLAST).

\subsection{Phylogenetic analysis}

Phylogenetic reconstructions were based on the sequences obtained in this study (the two Hepatozoon spp. sequences from the rodents and a $H$. canis sequence from a domestic dog) and 12 additional Hepatozoon spp. sequences retrieved from GenBank. Multiple alignment analysis was performed using the Clustal $\mathrm{X}$ version 2.0 (Larkin et al., 2007), and a phylogenetic tree was constructed based on the Neighbor-Joining algorithm and the Kimura 
two-parameter model for generating the distance matrix, as implemented in Molecular Evolutionary Genetics Analysis (MEGA) version 6 (Tamura et al., 2013). To estimate the confidence of the branching patterns in the Neighbor-Joining tree, we used the Bootstrap Test with 1000 replications (Felsenstein, 1985).

\subsection{Data analysis}

Cross Tabulation and a Chi-Square Test were used to verify the correlation between two types of categorical variables. In all analyses, the alpha level was set at 0.05 . Statistical tests were performed using IBM SPSS Statistics version 22.

\subsection{Ethical approval}

All animal procedures were conducted following approval by the Ethical Committee for Animal Research at the Instituto de Biociências/UNESP (CEUA-Comissão de Ética no Uso de Animais), protocol 431, and in accordance with Brazilian laws under a permanent scientific collection license approved by the Brazilian Institute of Environment and Renewable Natural Resources (IBAMA) through the System Authorization and Information on Biodiversity (SISBIO 36283-3).

\section{Results}

\subsection{H. canis in dogs}

Thirty-nine (24.6\%) of 158 dogs presented circulating Hepatozoon gametocytes in stained thin blood smears. PCR assays indicated that $66.45 \%(105 / 158)$ of the dogs were infected with Hepatozoon sp. The sequences obtained from 20 positive samples were $100 \%$ identical. Sequencing yielded sequences that were $99-100 \%$ identical to various $H$. canis genotypes that have been deposited in GenBank. A H. canis sequence from the dogs examined in our study has been deposited in the Genbank (accession number KU569168 ).

\subsection{Ectoparasites on $\mathrm{H}$. canis-infected dogs}

Of the 105 dogs that were positive for $H$. canis based on PCR analyses, $52.38 \%$ had at least one species of ectoparasite. The only flea species found, Ctenocephalides felis felis, was the most prevalent and abundant ectoparasite among the infected dogs ( $86.4 \%$ of 229 ectoparasites recovered). Thirty-four (61.81\%) of the dogs had infestations of that flea species. Ten $(18.1 \%)$ of the infected dogs were infested by ixodid ticks (13.5\% of all ectoparasites), which were of four species: $R$. sanguineus s.l. $(\mathrm{n}=18)$, A. ovale $(\mathrm{n}=6)$, Amblyomma sculptum $(\mathrm{n}=6)$, and $R$. microplus $(\mathrm{n}=1)$. The remaining 11 dogs (20\%) harbored mixed infestations by fleas and ticks. Neither the presence of ticks $\left(\chi^{2}=0.04, \mathrm{df}=1\right)$ nor the presence of fleas $\left(\chi^{2}=0.08, \mathrm{df}=1\right)$ were significantly $(\mathrm{p}>0.05)$ correlated with the presence of $H$. canis infections.

To recover $H$. canis oocysts, ticks from infected dogs were dissected. All but one (1.9\%) tested negative for the presence of parasitic forms. A single semi-engorged female $R$. microplus tick had 132 typical sporulated $H$. canis oocysts $(200.0 \pm 14.7 \times 158.9 \pm 6.0 \mu \mathrm{m})$.

\subsection{Hepatozoon spp. infections in wild rodents}

Thirty-seven (55.2\%) of the 67 rodents examined showed evidence of Hepatozoon spp. infection based on DNA in at least one type of tissue examined (blood, liver, spleen, and skeletal muscle). All of the rodent species captured were susceptible to infection (Table 1).

Thirty-seven partial Hepatozoon sp. 18S rRNA sequences were produced using the 4558 and 2733 primer set. The multiple align-
Table 1

Prevalence of Hepatozoon infections in rodents collected in the municipality of Botucatu, São Paulo, Brazil.

\begin{tabular}{lll}
\hline Rodent species & Number of specimens & $\begin{array}{l}\text { Hepatozoon PCR } \\
\text { positive } \\
\text { (prevalence\%) }\end{array}$ \\
\hline Oligoryzomys nigripes & 40 & $32.5 \%$ \\
Oligoryzomys flavescens & 3 & $100 \%$ \\
Akodon sp. & 19 & $89.5 \%$ \\
Necromys lasiurus & 4 & $75 \%$ \\
Sooretamys angouya & 1 & $100 \%$ \\
Total & 67 & $55.2 \%$ \\
\hline
\end{tabular}

ment identified two distinct Hepatozoon genotypes, designated Hepatozoon sp. genotype Rodent SP-1 and Hepatozoon sp. genotype Rodent SP-2, which had 13 nucleotide differences (1.3\%, 973/986). Most (33) of the sequences, which were identical, were from Hepatozoon sp. genotype Rodent SP-1 and were derived from the blood or tissue of 11 Akodon sp. and one 0 . nigripes. The remaining four sequences, which were identical, belonged to Hepatozoon sp. genotype Rodent SP-2 and were obtained from the blood, liver, and spleen of two $O$. flavescens specimens. The two Hepatozoon sequences identified in the present study have been deposited in GenBank as follows: Hepatozoon sp. genotype Rodent SP-1 (KU667308) and Hepatozoon sp. genotype Rodent SP-2 (KU667309).

The Hepatozoon genotypes were $99 \%$ identical to the following Hepatozoon sp. sequences available in GenBank: AB181504 (Hepatozoon sp. in a giant rat from Thailand), FJ719815, FJ719816, FJ719817, FJ719818, FJ719819 (Hepatozoon sp. in wild rodents from Chile), AY600625, AY600626, JX644997 (Hepatozoon sp. detected in sylvatic rodents from Europe), and EF157822 (a Hepatozoon ayorgbor sequence detected in the African snake Python regius). In addition, Hepatozoon sp. genotype Rodent SP-1 and Hepatozoon sp. genotype Rodent SP-2 were, respectively, 99\% and 98\% identical to Hepatozoon sp. Rodent MT (accession number KP757838) detected in wild rodents from the Brazilian Pantanal. Genetic similarities between the Hepatozoon isolates from rodents from São Paulo, Brazil, and the $H$. canis sequences from the dogs in the present study and $H$. canis sequences that have been deposited in the GenBank database [DQ43950 (Venezuela) and AY150067 (Spain)] were lower (95\%).

Histopathological examination of tissues revealed cystozoites within monozoic cysts (Fig. 1) in the spleen, lungs, and kidneys of $16.2 \%(n=37)$ of the Hepatozoon-infected rodents (Akodon sp.).

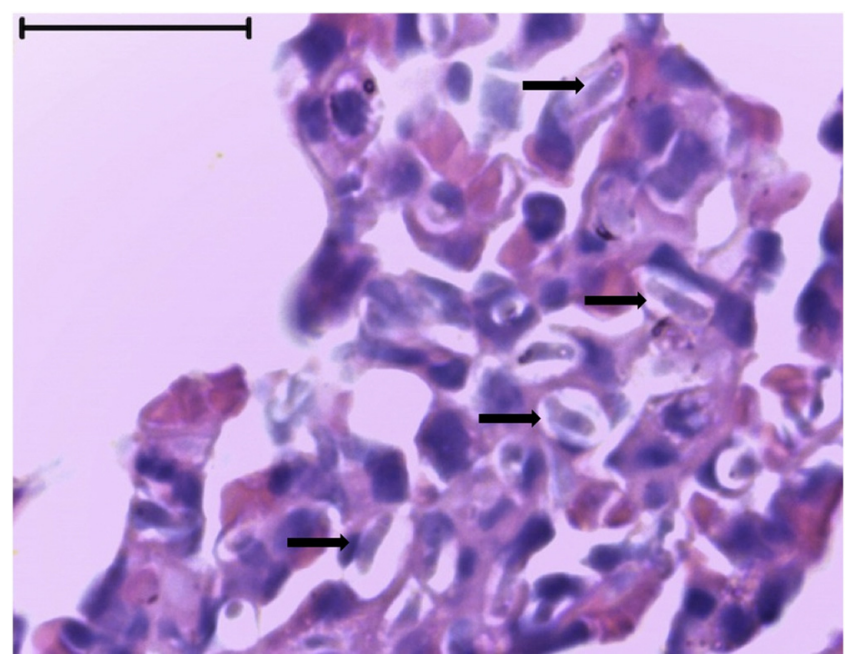

Fig. 1. Monozoic cysts containing cystozoites (arrows) in the lung of a naturally Hepatozoon-infected Akodon sp. from São Paulo, Brazil. Hematoxylin \& Eosin stain, Bar $=10 \mu \mathrm{m}$. 
On average, parasites measured $4.5 \pm 1.2 \times 1.6 \pm 0.5 \mu \mathrm{m}$. Hepatozoon sp. 18S rRNA sequences obtained from the tissues containing monozoic cysts were $100 \%$ identical to the sequence Hepatozoon sp. genotype Rodent SP-1.

\subsection{Phylogenetic analysis}

The Neighbor-Joining phylogenetic tree based on a 504-bp fragment of the 18S rRNA gene (Fig. 2) indicated that the Hepatozoon species detected in sylvatic rodents were distinct from the $H$. canis sequences detected in dogs from Brazil and other countries (bootstrap values ranged from 65 to 99). Although the sequences from rodents were grouped in a distinct cluster from an $\mathrm{H}$. americanum sequence (with bootstrap support of 84), they were closer to $H$. americanum than they were to $H$. canis isolates.

Hepatozoon sp. genotype Rodent SP-1 and Hepatozoon sp. genotype Rodent SP-2 grouped with Hepatozoon sequences from wild rodents from various countries. In addition, the two genotypes were positioned within a Hepatozoon spp. group detected in rodents from South America (FJ719816 and KP757838) and distinct from a Hepatozoon spp. group obtained from rodents in Europe (AY600626, KF418366, JX644997, AY600625). Hepatozoon sp. genotype Rodent SP-1 clustered close to H. ayorgbor, from an African ball python.

\section{Discussion}

More than a century ago, Christophers (1907) first identified the role of $R$. sanguineus s.l. ticks in the transmission of canine hepatozoonosis caused by $H$. canis. That tick species is the main vector of the disease in many regions of the world (Baneth et al., 2007; Giannelli et al., 2013). In Brazil, however, the $R$. sanguineus group does not appear to be involved in the transmission of $H$. canis, and efforts to identify tick species that might serve as competent vectors have not been successful (Forlano et al., 2005; Demoner et al., 2013). Small rodents can play a role through predation in the transmission of $\mathrm{H}$. americanum (Johnson et al., 2008b), which led us to suppose that predation might be a transmission route for $H$. canis. To our knowledge, our study is the first to investigate the relationships among Hepatozoon species that infect domestic canids and wild rodents in Brazil.

Molecular analyses revealed a high (66.45\%) prevalence of $H$. canis among apparently asymptomatic dogs from rural areas in Brazil, which was not unexpected because it appears to be a common parasite in rural areas of Brazil. Rubini et al. (2008) reported a $53.3 \%$ prevalence of canine hepatozoonosis in rural communities in São Paulo, Brazil. In rural areas of Minas Gerais, Brazil, de Miranda et al. (2014) found a high (84.3\%) prevalence of $H$. canis in domestic dogs. Moreover, $H$. canis infection was also very prevalent $(75.9 \%)$ in dogs from urban areas, which does not corroborate previous studies that found a prevalence ranging from $0.48 \%$ to $7.6 \%$ in dogs from urban areas in Brazil (Gomes et al., 2010; Ramos et al., 2010; Ramos et al., 2015).

In our study, although ectoparasite infestation and $\mathrm{H}$. canis infections were not correlated, most (61.8\%) of the infected dogs were infested by $C$. felis felis fleas. Canine hepatozoonosis is well- known to be transmitted by ticks (Baneth, 2011); however, some Hepatozoon species can be transmitted by other blood-sucking arthropods such as fleas, mosquitoes, mesostigmatid mites, and sandflies (Smith, 1996; Laison et al., 2003). In addition, fleas are invertebrate hosts of Hepatozoon spp. that infect mammals (Watkins et al., 2006). The role of ticks in the transmission of $H$. canis in Brazil is unclear and a high proportion of Hepatozoon-positive dogs were infested by fleas; therefore, there is value in assessing whether these ectoparasites have an important role as vectors of the disease in rural areas of Brazil, which might lead to new approaches for investigating epidemiological aspects of $H$. canis.

The proportion of the naturally $H$. canis-infected dogs that had tick infestations was low (18\%). In addition, only one (a R. microplus tick) of 31 ticks was infected with typical Hepatozoon sp. oocysts. de Miranda et al. (2011) found $H$. canis oocysts in a female $R$. microplus collected from a naturally infected dog. $R$. microplus is a one-host tick (Gonzales, 1974) and, probably, this ixodid does not play an important role in the transmission of the protozoan, primarily because transovarial transmission does not occur in Hepatozoon species (Baneth et al., 2007). Furthermore, dogs are not the preferred hosts of $R$. microplus (Franque et al., 2007), and its role in the epidemiology of $H$. canis remains questionable.

In the present study, none of $18 R$. sanguineus s.l. ticks collected from naturally infected dogs were infected with stages of Hepatozoon sp. Demoner et al. (2013) were unable to experimentally transmit $H$. canis to $R$. sanguineus s.l. ticks. Additionally, Melo et al. (2016) performed PCR for the detection of H. canis in R. sanguineus s.l. ticks $(n=320)$ collected from domestic dogs and none of the ticks tested positive. Collectively, these findings strongly indicate that the $R$. sanguineus group in Brazil does not act as a vector of $H$. canis.

Overall prevalence of Hepatozoon infection was high (55\%) among wild rodents in southeastern Brazil. Merino et al. (2009) detected unidentified Hepatozoon species in $47 \%$ of 17 rodents (Abrotrix olivaceus and Abrotrix sanborni). Maia et al. (2014) found a $41 \%$ prevalence of Hepatozoon parasites in wild rodents from North Africa. In North America, Hepatozoon spp. are highly prevalent in wild rodents. For example, in the USA, Johnson et al. (2007) detected Hepatozoon sp. in $58 \%$ of cotton rats and $33.3 \%$ of white-footed mice. Wolf et al. (2016) were the first to detect Hepatozoon sp. in sylvatic rodents in Brazil, reported a low (7\%) prevalence in Calomys callosus. Thus, apparently, Hepatozoon might be a common parasite of wild rodents worldwide. Differences between studies in the infection rates in Brazil might have been due to the geographical distribution of the parasite and the availability of suitable definitive hosts.

Analysis of the 18S rRNA gene sequences of Hepatozoon and the phylogenetic analysis clearly showed that the two Hepatozoon genotypes detected in wild rodents in southeastern Brazil are genetically distinct and phylogenetically distant from Hepatozoon species that infect dogs. In the USA, Johnson et al. (2007) obtained Hepatozoon sequences from wild rodents trapped in endemic areas for American canine hepatozoonosis that were genetically distinct from $H$. canis and H. americanum. Maia et al. (2014) performed phylogenetic analyses of Hepatozoon sequences from various predators (wild canids and snakes) and their prey (rodents and lizards) in North Africa and concluded that transmission by predation may occur less frequently between prey and canid predators than it does in predator-prey systems involving snakes and lizards. In addition, the Hepatozoon sequences obtained from wild rodents were not genetically related to $\mathrm{H}$. canis isolates. Those results encourage us to suggest that wild rodents are not involved in the transmission of $H$. canis to domestic dogs; therefore, they might not have a role in the transmission of canine hepatozoonosis in rural areas in southeastern Brazil.

The Hepatozoon sequences obtained from Brazilian rodents were genetically similar (99\%) to a $H$. ayorgbor sequence found in an African ball python, P. regius (Sloboda et al., 2008). In addition, Sloboda et al. (2008) transmitted $H$. ayorgbor to a snake by feeding it tissues from experimentally infected rodents, which suggests that there are three hosts (mosquito-rodent-serpent) in the life cycle of $H$. ayorgbor. Allen et al. (2011) identified a Hepatozoon sp. sequence from the snake Boa constrictor imperator that was very similar to rodent sequences. The transmission of Hepatozoon spp. from prey to snakes usually involves frogs or lizards as a paratenic host (Smith 1996; Smith et al., 1999); however, given those findings, we sus- 


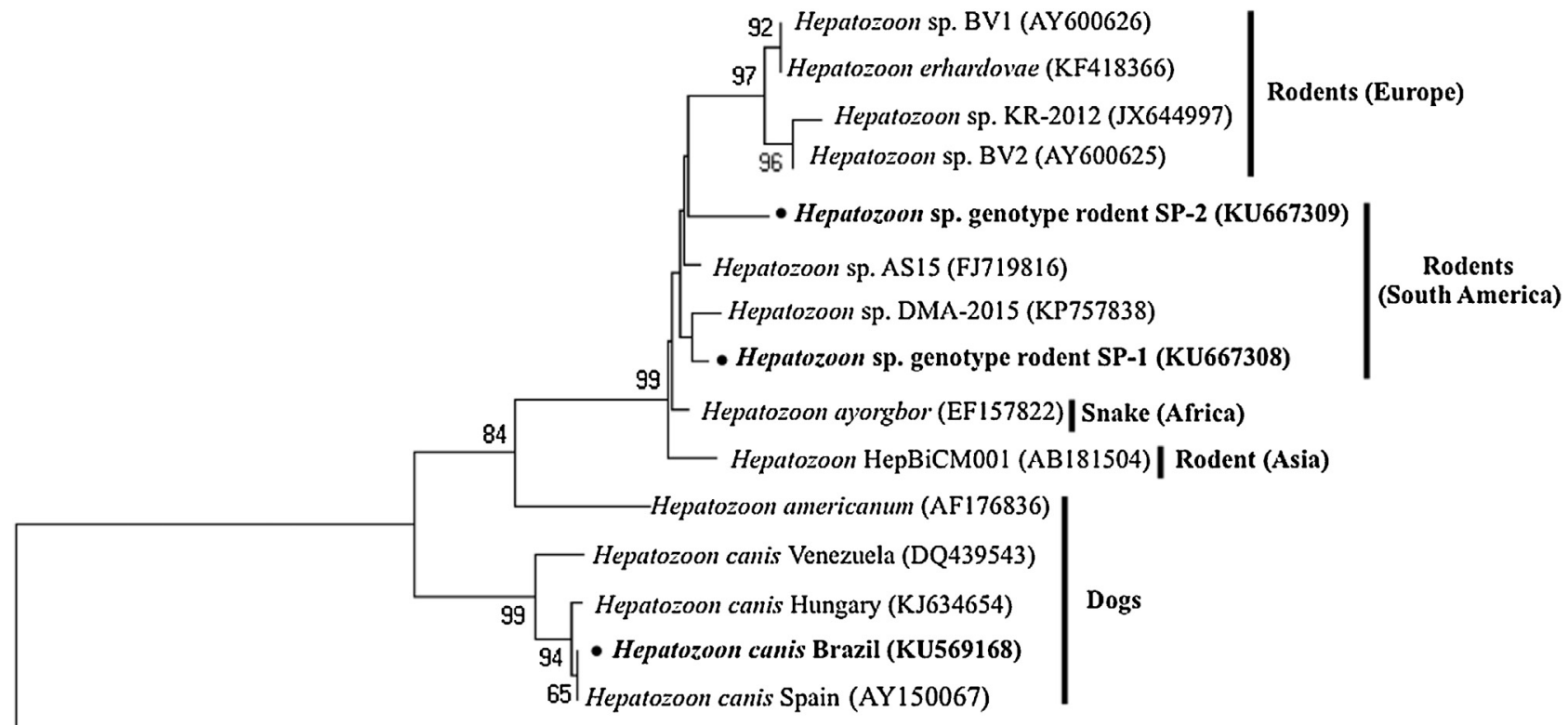

Babesia canis vogeli (AY371196)

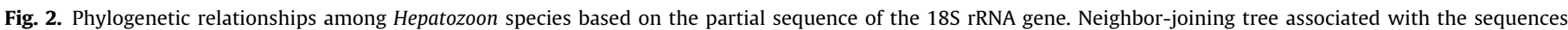

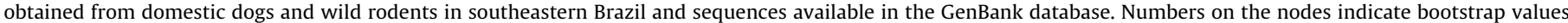

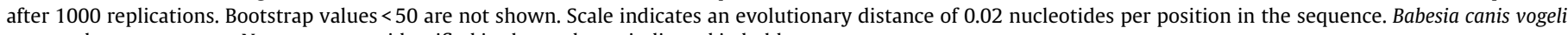
was used as an outgroup. New sequences identified in the study are indicated in bold.

pect that rodents have an important role in the transmission of Hepatazoon species that infect snakes.

Monozoic cysts that contained cystozoites were detected in some of the Hepatozoon-infected rodents, which is unlike previous studies that did not identify cysts in tissues from naturally infected rodents (Laakkonen et al., 2001; Johnson et al., 2007). Tissue cyst formation has been documented in Hepatozoon spp. that infect reptiles and anurans (Smith et al., 1994). Those cyst forms might be infective to intermediate host predators (Johnson et al., 2008a). Our study has shown that wild rodents in Brazil can be an intermediate host or a paratenic host of Hepatozoon spp., which underscores the need to understand the role that rodents might play in the epidemiology of Hepatozoon spp.

In conclusion, we identified two novel Hepatozoon genotypes that infect wild small rodents in Southeastern Brazil, which are not closely related to $H$. canis. Therefore, the question concerning how dogs in Brazil become infected remains without answers; however, because sylvatic rodents harbor infective tissue stages, they might be a source of infection for wild predators.

\section{Acknowledgements}

The authors are extremely grateful to Ana Paula Carmignotto from Federal University of São Carlos (Campus Sorocaba, São Paulo, Brazil) for identifying the rodent species. This research was supported by the Fundação de Amparo à Pesquisa do Estado de São Paulo (FAPESP Proc. $\mathrm{N}^{\circ} .2012 / 09715-0$ and FAPESP Proc. $\mathrm{N}^{\circ}$. 2012/25197-9).

\section{References}

Aktas, M., Özübek, S., Altay, K., Balkaya, I., Utuk, A.E., Kırbase, A., Simsek, S., Dumanl, N., 2015. A molecular and parasitological survey of Hepatozoon canis in domestic dogs in Turkey. Vet. Parasitol. 209, 264-267.
Allen, K.E., Yabsley, M.J., Johnson, E.M., Reichard, M.V., Panciera, R.J., Ewing, S.A., Little, S.E., 2011. Novel Hepatozoon in vertebrates from the southern United States. J. Parasitol. 94, 648-653.

Baneth, G., Mathew, J.S., Shkap, V., Mancitire, D.K., Barta, J.R., Ewing, S.A., 2003. Canine hepatozoonosis: two disease syndromes caused by separate Hepatozoon spp. Trends Parasitol. 19, 27-31.

Baneth, G., Samish, M., Shkap, V., 2007. Life cycle of Hepatozoon canis (Apicomplexa: adeleorina: hepatozoidae) in the tick Rhipicephalus sanguineus and domestic dog (Canis familiaris). J. Parasitol. 93, 283-299.

Baneth, G., 2011. Perspectives on canine and feline hepatozoonosis. Vet. Parasitol. $181,3-11$

Barros-Battesti, D.M., Arzua, M., Bechara, G.H., 2006. Carrapatos de importância médico-veterinária da região Neotropical-Um guia ilustrado para identificação de espécies. São Paulo: Vox/International Consortium on Ticks and Tick-borne Diseases/Butantan, 223 p.

Christophers, S.R., 1907. The sexual cycle of Leucocytozoon canis in the tick: scient. Mem. Off. Med. Sanit. Dept. Gov. India 28, 1-14.

Criado-Fornelio, A., Ruas, J.L., Casado, N., Farias, N.A.R., Soares, M.P., Müller, G., Brum, J.G.W., Berne, M.E.A., Buling-Saraña, A., Barba-Carretero, J.C., 2006. New molecular data on mammalian Hepatozoon species (Apicomplexa: adeleorina) from Brazil and Spain. J. Parasitol. 92, 93-99.

Dantas-Torres, F., Otranto, D., 2015. Further thoughts on the taxonomy and vector role of Rhipicephalus sanguineus group ticks. Vet. Parasitol. 208, 9-13.

Demoner, L.C., Rubini, A.S., Paduan, K.S., Metzger, B., Antunes, J.M.A.P., Martins, T.F. Mathias, M.I.C., O'Dwyer, L.H., 2013. Investigation of tick vectors of Hepatozoon canis in Brazil. Ticks Tick Borne Dis. 4, 542-546.

Felsenstein, J., 1985. Confidence limits of phylogenies: an approach using the bootstrap. Evolution 39, 783-791.

Forlano, M., Scofield, A., Elisei, C., Fernandes, K.R., Ewing, S.A., Massard, C.L., 2005. Diagnosis of Hepatozoon spp. in Amblyomma ovale and its experimental transmission in domestic dogs in Brazil. Vet. Parasitol. 134, 1-7.

Franque, M.P., Santos, H.A., da Silva, G.V.O., Tajiri, J.T., Massard, C.L., 2007. Biological characteristics of Boophilus microplus (Acari: ixodidae) on dog under experimental infestation. Braz. J. Vet. Parasitol. 16, 238-242.

Giannelli, A., Ramos, R.A., Di Paola, G., Mencke, N., Dantas-Torres, F., Baneth, G., Otranto, D., 2013. Transtadial transmission of Hepatozoon canis from larvae to nymphs of Rhipicephalus sanguineus. Vet. Parasitol. 196, 1-5.

Gomes, P.V., Mundim, M.J.S., Mundim, A.V., de Ávila, D.F., Guimarães, E.C., Cury, M.C., 2010. Occurrence of Hepatozoon sp: in dogs in the urban area originating from a municipality in southeastern Brazil. Vet. Parasitol. 175, 155-161.

Gonzales, J.C., 1974. O carrapato do boi: vida, resistência e controle. Mestre Jou, São Paulo, $101 \mathrm{p}$.

Hall, T.A., 1999. BioEdit: a user-friendly biological sequence alignment editor and analysis program for windows 95/98/NT. Nucleic Acids Symp. Ser. 41, 95-98.

Hornok, S., Tánczos, B., Fernández de Mera, I.G., de la Fuente, J., Hofmann-Lehmann, R., Farkas, R., 2013. High prevalence of 
Hepatozoon-infection among shepherd dogs in a region considered to be free of Rhipicephalus sanguineus. Vet. Parasitol. 196, 189-193.

Inokuma, H., Okuda, M., Ohno, K., Shimoda, K., Onishi, T., 2002. Analysis of the $18 \mathrm{~S}$ rRNA gene sequence of a Hepatozoon detected in two Japonese dogs. Vet. Parasitol. 106, 265-271.

Johnson, E.M., Allen, K.E., Panciera, R.J., Ewing, S.A., Little, S.E., Reichard, M.V., 2007. Field survey of rodents for Hepatozoon infections in an endemic focus of American canine hepatozoonosis. Vet. Parasitol. 150, 27-32.

Johnson, E.M., Allen, K.E., Breshears, M.A., Panciera, R.J., Little, S.E., Ewing, S.A., 2008a. Experimental transmission of Hepatozoon americanum to rodents. Vet. Parasitol. 151, 164-169.

Johnson, E.M., Allen, K.E., Panciera, R.J., Little, S.E., Ewing, S.A., 2008b. Infectivity of Hepatozoon americanum cystozoites for a dog. Vet. Parasitol. 154, 148-150.

Johnson, E.M., Allen, K.E., Panciera, R.J., Ewing, S.A., Little, S.E., 2009a. Experimental transmission of Hepatozoon americanum to New Zealand White rabbits (Oryctolagus cuniculus) and infectivity of cystozoites for a dog. Vet. Parasitol. 164, 162-166.

Johnson, E.M., Panciera, R.J., Allen, K.E., Sheets, M.E., Beal, J.D., Ewing, S.A., Little, S.E., 2009b. Alternate pathway of infection with Hepatozoon americanum and the epidemiologic importance of predation. J. Vet. Intern. Med. 23, 1315-1318.

Laakkonen, J., Sukura, A., Oksanen, A., Henttonen, H., Soveri, T., 2001.

Haemogregarines of the genus Hepatozoon (Apicomplexa: adeleina) in rodents from northern Europe. Folia Parasitol. 48, 263-267.

Laison, R., Paperna, I., Naiff, R.D., 2003. Development of Hepatozoon caimani (Carini 1909) Pessôa, De Biasi \& De Souza, 1972 in the caiman Caiman c crocodilus, the frog Rana catesbeiana and the mosquito Culex fatigans. Mem. Inst. Oswaldo Cruz. 98, 103-113.

Larkin, M.A., Blackshields, G., Brown, N.P., Chenna, R., McGettigan, P.A., McWilliam, H., Valentin, F., Wallace, I.M., Wilm, A., Lopez, R., Thompson, J.D., Gibson, T.J., Higgins, D.G., 2007. Clustal W and clustal X version 2.0. Bioinformatics 23, 2947-2948.

Linardi, P.M., Santos, J.L.C., 2012. Ctenocephalides felis felis vs. Ctenocephalides canis (Siphonaptera: Pulicidae): some issues in correctly identify these species. Braz. J. Vet. Parasitol. 21, 345-354

Maia, J.P., Alvares, F., Boratynski, Z., Brito, J.C., Leite, J.V., Harris, D.J., 2014 Molecular assessment of Hepatozoon (Apicomplexa: adeleorina) infections in wild canids and rodents from North Africa, with implications for transmission dynamics across taxonomic groups. J. Wildl. Dis. 50, 837-848.

Martins, T.F., Onofrio, V.C., Barros-Battesti, D.M., Labruna, M.B., 2010. Nymphs of the genus Amblyomma (Acari Ixodidae) of Brazil: descriptions, redescriptions, and identification key. Ticks Tick Borne Dis. 1, 75-99.

Mathew, J.S., Van Den Bussche, R.A., Ewing, S.A., Malayer, J.R., Latha, B.R., Panciera, R.J., 2000. Phylogenetic relationships of Hepatozoon (Apicomplexa: adeleorina) based on molecular, morphologic, and life cycle characters. J. Parasitol. 86, 366-372.

Melo, A.L.T., Witter, R., Martins, T.F., Pacheco, T.A., Alves, A.S., Chitarra, C.S., Dutra, V., Nakazato, L., Pacheco, R.C., Labruna, M.B., Aguiar, D.M., 2016. A survey of tick-borne pathogens in dogs and their ticks in the Pantanal biome. Brazil. Med. Vet. Entomol. 30, 112-116.

Merino, S., Vásquez, R.A., Martínez, J., Celis-Diez, J.L., Gutiérrez-Jiménez, L., Ippi, S., Sánchez-Monsalvez, I., de la Puente, J.M., 2009. Molecular characterization of an ancient Hepatozoon species parasitizing the 'living fossil' marsupial 'Monito del Monte' Dromiciops gliroides from Chile. Biol. J. Linn. Soc. 98, 568-576.

Mills, J.N., Childs, J.E., Ksiazek, T.G., Peters, M.D., Velleca, W.M., 1995. Methods for Trapping and Sampling Small Mammals for Virologic Testing. US Department of Health and Human Services, Public Health Service, Centers for Disease Control and Prevention, Atlanta, $61 \mathrm{p}$

Murata, T., Inoue, M., Tateyama, S., Taura, Y., Nakama, S., 1993. Vertical transmission of Hepatozoon canis in dogs. J. Vet. Med. Sci. 55, 867-868.
Nava, S., Estrada-Peña, A., Petney, T., Beati, L., Labruna, M.B., Szabó, M.P.J., Venzal, J.M., Mastropaolo, M., Mangold, A.J., Guglielmone, A.A., 2015. The taxonomic status of Rhipicephalus sanguineus (Latreille, 1806). Vet. Parasitol. 208, 2-8.

O’Dwyer, L.H., 2011. Brazilian canine hepatozoonosis. Braz. J. Vet. Parasitol. 20 181-193.

Peres, M.G., Bacchiega, T.S., Appolinário, C.M., Vicente, A.F., Allendorf, S.D., Antunes, J.M.A.P., Moreira, S.A., Legatti, E., Fonseca, C.R., Pituco, E.M.M., Okuda, L.H., Pantoja, J.C.F., Ferreira, F., Megid, J., 2013. Serological study of vaccinia virus reservoirs in areas with and without official reports of outbreaks in cattle and humans in São Paulo. Brazil. Arch. Virol. 158, 2433-2441.

Ramos, R., Ramos, C., Araújo, F., Oliveira, R., Souza, I., Pimentel, D., Galindo, M. Santana, M., Rosas, E., Faustino, M., Alves, L., 2010. Molecular survey and genetic characterization of tick-borne pathogens in dogs in metropolitan Recife (north-eastern Brazil). Parasitol. Res. 107, 1115-1120.

Ramos, C.A.N., Babo-Terra, V.J., Pedroso, T.C., Filho, A.F.S., de Araújo, F.R., Cleveland H.P.K., 2015. Molecular identification of Hepatozoon canis in dogs from Campo Grande, Mato Grosso do Sul, Brazil. Braz. J. Vet. Parasitol. 24, 247-250.

Rubini, A.S., Paduan, K.S., Lopes, V.V.A., O’Dwyer, L.H., 2008. Molecular and parasitological survey of Hepatozoon canis (Apicomplexa Hepatozoidae) in dogs from rural area of São Paulo state, Brazil. Parasitol. Res. 102, 895-899.

Rubini, A.S., Paduan, K.S., Martins, T.F., Labruna, M.B., O’Dwyer, L.H., 2009. Acquisition and transmission of Hepatozoon canis (Apicomplexa: hepatozoidae) by the tick Amblyomma ovale (Acari: ixodidae). Vet. Parasitol. 164, 324-327.

Sloboda, M., Kamler, M., Bulantová, J., Votyípka, J., Modryí, T.G., 2008. Rodents as intermediate hosts of Hepatozoon ayorgbor (Apicomplexa: adeleina: hepatozoidae) from the African ball python, Python regius? Folia Parasitol. 55, 13-16.

Smith, Desser, S.S., Martin, D.S., 1994. The development of Hepatozoon sipedon sp. nov. (Apicomplexa Adeleina: hepatozoidae) in its natural host, the Northern water snake (Nerodia sipedon sipedon), in the culicine vectors, Culex pipiens and C. territans, and in an intermediate host, the Northern leopard frog (Rana pipiens). Parasitol. Res. 80, 559-568.

Smith, T.G., Kim, B., Desser, S.S., 1999. Phylogenetic relationships among Hepatozoon species from snakes, frogs and mosquitoes of Ontario Canada, determined by ITS-1 nucleotide sequences and life-cycle, morphological and developmetal characteristics. Int. J. Parasitol. 29, 293-304.

Smith, T.G., 1996. The genus Hepatozoon (Apicomplexa: adeleina). J. Parasitol. 82 $565-585$.

Tamura, K., Stecher, G., Peterson, D., Filipski, A., Kumar, S., 2013. MEGA6: molecular evolutionary genetics analysis version 6.0. Mol. Biol. Evol. 30, 2725-2729.

Ujvari, B., Madsen, T., Olsson, M., 2004. High prevalence Hepatozoon spp. (Apicomplexa, Hepatozoidae) infection in water pythons (Liasis fuscus) from tropical Australia. J. Parasitol. 90, 670-672.

Watkins, R.A., Moshier, S.E., Pinter, A.J., 2006. The Flea, Megabothris abantis An invertebrate host of Hepatozoon sp. and a likely definitive host in Hepatozoon infections of the Montane Vole, Microtus montanus. J Wildl. Dis, 42, 386-390.

Wolf, R.W., Aragona, M., Muñoz-Leal, S., Pinto, L.B., Melo, A.L.T., Braga, I.A., Costa, J.S., Martins, T.F., Marcili, A., Pacheco, R.C., Labruna, M.B., Aguiar, D.M., 2016. Novel Babesia and Hepatozoon agents infecting non-volant small mammals in the Brazilian Pantanal, with the first record of the tick Ornithodoros guaporensis in Brazil. Ticks Tick Borne Dis. 7, 449-456.

de Miranda, R.L., Castro, J.R., Olegário, M.M.M., Beletti, M.E., Mundim, A.V., O’Dwyer, L.H., Eyal, O., Talmi-Frank, D., Cury, M.C., Baneth, G., 2011. Oocysts of Hepatozoon canis in Rhipicephalus (Boophilus) microplus collected from a naturally infected dog. Vet. Parasitol. 177, 392-396.

de Miranda, R.L., O’Dwyer, L.H., de Castro, J.R., Metzger, B., Rubini, A.S., Mundim, A.V., Eyal, O., Talmi-Frank, D., Cury, M.C., Baneth, G., 2014. Prevalence and molecular characterization of Hepatozoon canis in dogs from urban and rural areas in Southeast Brazil. Res. Vet. Sci. 97, 326-329. 